\title{
AMAR
}

AMAR (Andalas Management Review)

Vol. 4, No. 1 (2020) 18-39

The Management Institute, Faculty of Economics, Universitas Andalas

ISSN (Print) 2476-9282 | ISSN (Online) 2548-155X

\section{Pembuktian Return Momentum dan Kontrarian pada Saham Syariah}

\author{
Nanda $^{a}$, Fajri Adrianto ${ }^{b}$ \\ aMagister Manajemen Fakultas Ekonomi Universitas Andalas, danan_com@yahoo.co.id \\ ${ }^{b}$ Magister Manajemen Fakultas Ekonomi Universitas Andalas, fajriadrianto@eb.unand.ac.id
}

\begin{abstract}
The purpose of this paper are to examine and analyse returns of momentum and contarian portofolio on Islamic stocks listed on the Jakarta Islamic Index 30 (JII 30) for the period 2010-2018. The method used in this study is Jagedeesh and Titmant (1993). Winner portfolio is formed by buying stocks with the best return performance in the past and selling stocks with bad returns in the past. Whereas a loser portfolio is formed by buying shares of poor return performance in the past and selling stocks with good returns in the past. Formations and observations used 1,3,6 and 12 months. With portfolio weighting based on equal-weighted and value-weighted. Return of momentum portofolio when winner minus loser positive. Return of contarian portofolio when loser minus winner positive. Significant contours are determined by a one-sample t-test using SPSS 25. The study did not find any return on the Islamic stocks listed on JII 30 for the period 2010-2018. But investors can still use this strategy to increase investment returns on Islamic stocks. Because this strategy still provides positive returns.
\end{abstract}

Keyword: winner portofolio, loser portofolio, momentum, contarian

\section{PENDAHULUAN}

Salah satu faktor penting dalam pertumbuhan ekonomi sebuah negara adalah investasi. Menurut Bodie, Kane \& Marcus (2011) investasi bisa berbentuk investasi aset rill dan investasi aset finansial. Investasi aset finansial merupakan salah satu wahana investasi yang berkembang di zaman sekarang karena investasi ini dianggap lebih praktis. Investasi finansial ini secara keseluruhan terdiri dari dua jenis yaitu investasi pasar uang dan pasar modal. Dalam perkembangan pasar modal di Indonesia, Indonesia sebagai negara dengan penduduk muslim terbanyak di dunia, sehingga memiliki pangsa pasar modal syariah terbesar di dunia. Pasar modal syariah adalah seluruh kegiatan di pasar modal yang tidak bertentangan dengan prinsip-prinsip Islam. Pasar modal syariah Indonesia merupakan bagian dari industri keuangan syariah yang diatur oleh Otoritas Jasa Keuangan, khususnya direktorat pasar modal syariah (Sumber: BEI Syariah 2019). 
Reksadana syariah merupakan produk pertama yang diluncurkan oleh pasar modal syariah Indonesia pada tahun 1997. Setahun kemudian diluncurkan Jakarta Islamic Index (JII) yang merupakan Indeks saham syariah pertama yang terdiri dari 30 saham syariah paling likuid di BEI. Saat ini indeks syariah di pasar modal Indonesia. Selain Jakarta Islamic Index (JII) yang terdiri dari 30 syariah terlikuid, juga terdapat Jakarta Islamic Indeks 70 (JII70) dan Indeks Saham Syariah Indonesia (ISSI). Dimana review saham yang masuk kedalam indeks tersebut dilakukan sekali enam bulan setiap bulan Mei dan November (Sumber: BEI Syariah 2019) .

Tabel 1

Kapitalisasi pasar saham syariah

di Bursa Efek Indonesia

\begin{tabular}{cccc}
\hline Tahun & $\begin{array}{c}\text { Jakarta Islamic } \\
\text { Index }\end{array}$ & $\begin{array}{c}\text { Indeks Saham } \\
\text { Syariah } \\
\text { Indonesia }\end{array}$ & $\begin{array}{c}\text { Jakarta Islamic } \\
\text { Index 70 }\end{array}$ \\
\hline 2010 & $1.134 .632,00$ & - & - \\
2011 & 1.414 .983 .81 & 1.968 .091 .37 & - \\
2012 & 1.671 .004 .23 & $2.451 .33 .4,37$ & - \\
2013 & $1.672 .099,91$ & $2.557 .846,77$ & - \\
2014 & $1.944 .531,70$ & 2.946 .892 .79 & - \\
2015 & $1.737 .290,98$ & $2.600 .850,72$ & - \\
2016 & $2.035 .189,92$ & $3.170 .056,08$ & - \\
2017 & $2.288 .015,67$ & $3.704 .543,09$ & - \\
2018 & $2.239 .507,78$ & $3.861 .688,31$ & $2.715 .851,74$ \\
2019 (Februari) & $2.281 .962,48$ & $3.819 .522,48$ & $2.800 .124,53$
\end{tabular}

Sumber data diolah: Statistik Pasar Modal Syariah Otoritas Jasa Keuangan

Dari data ini dapat dilihat bahwa semenjak Indeks syariah pertama kali diperkenalkan melalui Jakarta Islamic Index (JII), secara umum kapitalisasi JII terus mengalami peningkatan. Selain itu jumlah indeks syariah juga terus mengalami peningkatan dan kapitalisasinya juga terus tumbuh. Ini mengidentifikasikan bahwa saham syariah berkembang dengan baik di Indonesia. Perkembang saham syariah ini sebagai alasan ketertarikan penulis untuk meneliti strategi investasi pada saham syariah lebih mendalam.

Teori Efficient Market Hypothesis (EMH) yang diperkenalkan oleh Fama (1970) menyatakan bahwa harga saham selalu mencerminkan semua informasi yang tersedia sehingga tidak bisa diperoleh abnormal retur dan harga saham bergerak secara acak (Jones, 2010). Teori EMH ini mendapat tantangan dari para akademisi yang mengatakan bahwa 
harga saham dipengaruhi oleh prilaku investor sehingga abnormal return yang bisa diperoleh dari pasar. Seperti dengan strategi kontarian yang pertama kali dikemukan oleh DeBondt \& Thaler (1985) abnormal return dapat diperoleh dengan membeli saham yang memiliki kinerja jelek dimasa lalu. sedangkan Jegadeesh \& Titman (1993) memperkenalkan strategi momentum untuk memperoleh abnormal return di pasar yaitu dengan membeli saham dengan kinerja baik dimasa lalu.

Dasar dari strategi investasi kontrarian adalah hipotesis overreaction dimana menurut hipotesis ini investor cenderung akan overreaction terhadap informasi positif atau negatif. De Bondt \& Thaler (1985) melakukan penelitian menggunakan data pasar modal Amerika Serikat, mereka menemukan bahwa saham-saham yang pada mulanya memberikan tingkat return positif (winner) atau negatif (loser) akan mengalami pembalikan (reversal) pada periode-periode berikutnya.

Berbeda dengan strategi investasi kontrarian, strategi investasi momentum yang pertama kali dikemukakan oleh Jegadeesh \& Titman (1993) merupakan penentang strategi kontarian dengan membeli saham dengan kinerja yang bagus dimasa lalu dan menjual saham berkinerja buruk dimasa lalu. Strategi ini berdasarkan underreaction harga saham terhadap faktor yang menyebabkan overreaction sehingga trend harga akan terus berlanjut sampai terjadi pembalikan yang di sebabkan oleh overreaction. Strategi ini memanfaatkan momentum pergerakan kenaikan harga saham dengan harapan kenaikan harga saham tersebut terus berlanjut.

Semenjak strategi momentum dan kontarian di perkenalkan, sudah banyak penelitian terkait strategi ini di pasar keuangan diseluruh dunia. Dan menghasilkan banyak perdebatan di antara para peneliti tentang ada tidaknya anomali ini dan serta strategi mana yang lebih menguntung kontarian atau momentum untuk periode jangka pendek, menengah dan panjang. Selain metode penelititian terhadap strategi momentum dan kontarian, penyebab dari anomali momentum dan kontarian juga terus dikembangkan. Serta strategi ini juga sering dihubungkan dengan dengan beberapa faktor seperti size, profitabilitas, volume transaksi, tiga faktor model fama-French, dan factor harga under and overreaction (Bhootra, 2018).

Penelitian terhadap return dari strategi momentum dan kontarian telah dilakukan di pasar modal Indonesia. seperti Nugroho (2008) meneliti momentum pada saham yang tercatat di BEI. Dewi \& Sasmikadewi (2017) meneliti return portofolio momentum dan kontarian pada industri keuangan. Saputro \& Badjra (2016) meneliti return momentum pada industri manufaktur. Witiastuti \& Maharani (2015) meneliti market overreaction pada saham 
di BEI yang aktif diperdagangkan. Khairunnisa, Rikumahu \& Valentina (2017) yang meneliti price reversal pada Indeks bisnis 27. Arfianto \& Maharani (2016) meneliti return momentum pada Indeks Kompas 100.

Belum adanya Penelitian momentum dan kontrarian di pasar modal Indonesia yang melihat fenomena ini pada Indeks syariah serta perkembangan saham syariah di Indonesia yang terus mengalami peningkatan semenjak Indeks syariah diperkenalkan. Sehingga peneliti tertarik untuk membuktikan apakah terdapat return momentum dan kontrarian pada saham syariah. Penelitian ini akan meneliti Jakarta Islamic Indeks 30 (JII 30) untuk periode 2010 - 2018, karena JII 30 merupakan 30 saham syariah terliquid yang diperdagangkan di BEI.

\subsection{Strategi Momentum}

Selama dua dekade terakhir, telah banyak penelitian lebih lanjut yang dilakukan untuk memperkuat bukti empiris profitabilitas strategi momentum. Strategi momentum sekarang telah ditemukan tidak hanya di pasar saham AS tetapi juga di pasar saham negara lain (Stork, 2013). Penelitian strategi momentum juga telah dikembangkan dengan melihat pengaruh faktor size, value, earning, volume dan lainnya terhadap strategi momentum.

Investigasi strategi momentum pertama kali dilakukan oleh Jegedeesh \& Titman (1993). Mereka menggunakan data NYSE dan AMEX untuk periode 1965 hingga 1989, investigasi ini dilakukan dengan cara memberi peringkat Saham NYSE dan AMEX berdasarkan kinerja return masa lalu saham tersebut selama periode satu, dua, tiga dan empat kuartal. Kemudian membentuk sepuluh portofolio saham, dengan saham return tertinggi akan dimasukkan kedalam portofolio winner dan sebaliknya saham dengan return rendah dimasukkan dalam portofolio loser. Kinerja dari strategi momentum di ukur dengan membeli portofolio saham winner dan menjual portofolio saham loser, selama holding periods satu sampai empat kuartal. Penelitian ini menemukan portofolio dengan membeli saham winner dan menjual saham loser menghasilkan abnormal returns.

Scrimgeour, Locke \& Gupta (2013) melakukan studi global terhadap return momentum yang berfokus pada desain portofolio dan metode komputasi. Hasil penelitian ini mengklarifikasi dampak dari beberapa faktor yang berkontribusi pada estimasi return momentum. Sehingga return momentum berubah. Sampel besar dari data yang telah disesuaikan yang menjadi dasar studi ini memberikan tingkat kepercayaan yang lebih tinggi bahwa temuan-temuan tersebut masuk akal dan bukan hanya anomali statistik. 
Tanna \& Nnadi (2017) melakukan penelitian terhadap dari momentum dan kontrarian di negara Brazil, Russia, India, China dan Afrika Selatan (BRICS). penelitian ini berdasarkan metode Jegadeesh \& Titman (1993). Penelitian ini menemukan dari kelima pasar menunjukkan karakteristik yang berbeda, pasar modal India menunjukkan momentum efek terkuat. Pasar saham di Tiongkok dan Brasil menunjukkan profit kontrarian yang signifikan untuk jangka pendek dan profit momentum untuk jangka menengah hingga jangka panjang. Sementara Afrika Selatan menunjukkan efek momentum jangka pendek dan efek kontarian untuk jangka menengah hingga jangka panjang. Pasar saham Rusia menunjukkan pengembalian portofolio momentum sebagian besar tidak signifikan.

Stork (2013) meneliti mekanisme sementara dari return momentum dalam pasar. Penelitian ini meneliti mekanisme return momentum dari pasar saham untuk sepuluh negara yang berbeda. Hasil study ini menemukan return momentum positif mengikuti pasar yang sedang bullish dan negatif mengikuti pasar bearish. Brandao, Martins \& Martins (2016) penelitian ini bertujuan untuk melihat dampak dari anomali momentum di pasar keuangan Jerman. Metode yang digunakan dalam penelitian ini adalah metode Jagadeesh \& Titmant (1993). Penelitian ini menemukan terdapat return momentum yang signifikan di FSE. Sedangkan ukuran perusahaan memiliki hubungan yang negatif dengan return momentum.

Badjra \& Saputro (2016) menguji kinerja portofolio saham winner dibandingkan dengan kinerja portofolio saham loser di Bursa Efek Indonesia (BEI). Hasil penelitian ini kinerja portofolio saham winner, menghasilkan kinerja yang lebih rendah dibandingkan dengan kinerja yang dihasilkan portofolio saham loser. Dewi \& Sasmikadewi (2017), meneliti kinerja portofolio saham winner dan loser. Hasil penelitian ini menemukan kinerja portofolio saham winner menghasilkan kinerja yang lebih rendah dibandingkan dengan kinerja yang dihasilkan portofolio saham loser pada periode kepemilikan selanjutnya.

Bhootra (2018) meneliti kombinasi profitabilitas dan strategi momentum menghasilkan return yang superior memanfaatkan dua strategi yaitu jangka panjang mengunakan profitabilitas dan jangka pendek mengunakan strategi momentum. Hasil dari penelitian ini menunjukan kombinasi gross profit dan strategi momentum meningkatkan kinerja return dari portofolio dibanding dengan return portofolio yang dibentuk secara terpisah antara strategi momentum dan gross profit. Conrad \& Yavuz (2017) meneliti apakah terdapat hubungan yang luas antara momentum jangka pendek dan reversal untuk jangka panjang. Dan memeriksa apakah bisa mengidentifikasi kondisi sebelum terjadinya reversal pada portofolio momentum. Hasil dari semua tes ini menemukan terdapat return 
momentum dan kontrarian, dan memperlihatkan bahwa momentum dan pola reversal terpisah dan berbeda.

Dobrynskaya (2017) meneliti waktu momentum mengalami crash dan menunjukkan bahwa strategi momentum cenderung crash dalam 1-3 bulan setelah pasar modal mengalami crash. Selanjutnya, peneliti mengusulkan dynamic momentum and kontrarian trading. Du (2012) melakukan penelitian kembali sumber profitabilitas momentum dengan fokus pada return momentum bulanan. Berbeda dari penelitian sebelumnya, Du ingin melihat apakah faktor risiko atau prilaku yang menjadi sumber momentum. Hasil dari penelitian Du menyarankan penolakan terhadap asset-pricing models sebagai sumber momentum dan menerima mis-reaction sebagai sumber momentum.

Gunasekarage \& Kot (2007) meneliti tentang profitabilitas strategi momentum yang dilakukan di pasar saham Selandia Baru. Penelitian ini menemukan adanya momentum harga yang terjadi di pasar saham Selandia Baru. Moskowitz \& Daniel (2016) meneliti tentang momentum crash, dan menemukan strategi kontarian sesuai digunakan ketika pasar reboud dan strategi momentum sesuai ketika pasar normal. Aarts \& Lehnert (2006) menginvestigasi profitabilitas strategi momentum berdasarkan style yang berbeda. Sembilan style portofolio yang berbeda dimensi dari small cap vs large cap didasarkan kepada kapitalisasi pasar perusahaan dan value vs growth didasarkan kepada B/M rasio. Perusahaan dengan $\mathrm{B} / \mathrm{M}$ rasio negatif tidak dimasukan ke dalam sampel penelitian. Hasil penelitian ini tidak ada pembuktian yang style strategi momentum berkinerja lebih baik dari strategi momentum reguler. Sehingga strategi style momentum tidak memberi nilai tambah untuk investor Ingris.

Seperti banyak anomali lainnya, penjelasan momentum efek merupakan perdebatan yang kontroversial di berbagai literatur dan bisa dikategorikan berdasarkan resiko dan bukan resiko. Daniel et al., (1998) menyatakan bahwa prilaku sebagai penjelasan dari efek momentum dan dasar dari terjadinya momentum karena adanya bias dalam proses informasi yang tidak sempurna. Berlawanan dengan teori prilaku Kaul \& Conrad (1998) menyatakan bahwa profit momentum sesuai dengan variasi cross-section dalam expected returns dan sesuai dengan variasi risiko.

Menurut Barroso \& Clara (2015) dibandingkan dengan faktor pasar, nilai, atau ukuran, momentum telah menawarkan investor rasio Sharpe tertinggi. Namun, momentum juga mengalami crash terburuk, membuat strategi tidak menarik bagi investor yang tidak menyukai skewness dan kurtosis negatif. Risiko momentum sangat bervariasi dari waktu ke waktu dan dapat diprediksi. Mengelola risiko ini berusaha untuk mengurangi crash dan 
hampir menggandakan rasio Sharpe dari strategi momentum. Mengelola risiko merupakan teka-teki yang besar dari strategi momentum

Umumnya penelitian yang dilakukan untuk menemukan sumber rasional dibalik anomali momentum, upaya tersebut umumnya gagal untuk menjelaskan anomali momentum. Kegagalan dari model rasional dalam menjelaskan return momentum memotivasi para akademisi untuk mengajukan penjelasan anomali ini berdasarkan variasi bias psikologi. Penjelasan berdasarkan perilaku menjelaskan return momentum sebagai sebuah hasil perdagangan investor dengan bias psikologi yang menyebabkan harga saham menjauh dari nilai fundamental. Namun sampai sekarang belum ada satu teori yang diterima sebagai penjelasan dalam memprediksi momentum (Dhankar \& Maheshwari, 2017).

\subsection{Strategi Kontrarian}

Strategi kontarian, yang didasarkan pada hipotesis overreaction, memberi peringkat saham berdasarkan kinerja masa lalu mereka dan merekomendasikan untuk membeli saham loser di masa dan menjual winner di masa lalu (Gunasekarage \& Kot, 2007) Investigasi overreaction yang dilakukan oleh De Bondt \& Thaler (1985). Mereka menggunakan data return bulanan dari semua saham yang diperdagangkan di NYSE dalam periode 57 tahun dari Januari 1926 hingga Desember 1982 dan memeriksa return dari portofolio saham winner dan loser. Hasil penelitian mereka mengungkapkan bahwa terjadi reversal yang menyebabkan portofolio loser mengungguli pasar dengan rata-rata 19,6 persen per tahun, sementara portofolio winner berkinerja buruk dari pasar sebesar 5,0 persen. Secara statistik portofolio loser signifikan mengungguli portofolio winner sebesar 24,6 persen per tahun.

Mereka menyimpulkan bahwa reversal return dihasilkan dari overreaction yang dinampakan oleh investor. investor overreaction terhadap berita baru, dan jika berita ini positif overoptimistic investor membuat harga saham menjadi overvalue, sementara jika berita baru tersebut negatif investor akan terlalu pesimis sehingga harga saham menjadi undervalue. Fenomena overreaction bisa hubungkan dengan representasi bias Galariotis (2014), bias ini menyebabkan mispricing, dan disusul dengan koreksi terhadap mispricing yang menyebabkan reversal.

Overreaction, misspricing dan reversal ini yang dijadikan sumber dari strategi kontrarian dalam mendapatkan abormal returns. Sehingga dalam strategi kontrarian pembentukan portofolio dilakukan dengan membeli saham yang mengalami penurunan di 
masa lalu dan menjual saham yang mengalami peningkatan dimasa lalu. Dalam rangka mendapatkan saham-saham yang salah harga, dan akan mengalami pembalikan arah harga.

Doan \& Brooks (2014) meneliti strategi momentum dan kontrarian di Australia periode 1992-2011. Mereka menemukan bahwa kontrarian merata untuk investasi jangka pendek sedangkan momentum mendominasi untuk jangka menengah dan panjang. Namun hanya kontrarian periode jangka pendek bekinerja lebih baik dan signifikan secara statistik. Liao (2016) meneliti bagaimana ukuran dari investor momentum dan kontrarian di pasar mempengaruhi keseimbangan harga saham, dan melihat kemungkinan penyebab yang mempengaruhi keuntungan untuk kedua jenis investor irasional ini. Peneliti menduga rational informed investor mempengaruhi prilaku irational investor. Peneliti menemukan informed investor memanipulasi harga aset, dan mengarah ke fenomena makro momentum dan reversal. Ketika jumlah investor momentum relatif tinggi, informed investor akan mencoba untuk tidak membawa harga kembali ke harga fundamental dan menyebabkan harga menjadi over price. Sebaliknya, ketika investor kontrarian yang relatif lebih banyak di pasar, karena adanya risiko fundamental, bahkan ketika berita baik muncul, informed investor akan menghindari harga saham over reaction, dan mengakibatkan fenomena under reaction.

Leung, Fung \& Yu (2019) memeriksa momentum dan kontrarian di pasar china pada tahun 2010. Setelah pemerintah china menguranggi aturan dalam batasan short-sale. Pasar modal di China berbeda dengan pasar modal di US dalam beberapa hal. Pertama, pasar modal di China di dominasi oleh individual investor dengan karakteristik tipe traders kontrarian. Kedua investor cenderung sebagai spekulan investor, Karena informasi pasar kurang transparan. Ketiga, pasar modal China masih kurang transparan. Penelitian ini mengunakan metode JT winner minus loser. Penelitian ini tidak menemukan return momentum strategi di china seperti di pasar US. Tetapi return dari strategi kontrarian.

Witiastuti \& Maharani (2015) meneliti market overreaction di Bursa Efek Indonesia selama periode 2009 sampai 2013. Populasi yang digunakan dalam penelitian ini adalah seluruh saham yang terdaftar di BEI. Sampel dari penelitian ini 26 saham yang aktif diperdagangkan. Periode formasi dan observasi dalam penelitian ini adalah 3, 6 dan 12 bulan. Analisis data menggunakan indikator market overreaction yang diperkenalkan oleh De Bondt dan Thaler (1985). Penelitian ini menemukan market overreaction di Bursa Efek Indonesia terjadi secara tidak signifikan.

Chen et al. (2015) juga melakukan investigasi profitabilitas dari strategi momentum dan kontrarian di pasar saham China untuk periode 1994-2013 mengunakan data Shanghai 
Stock Exchange dan Shenzhen Stock Exchange.. Penelitian ini memeriksa profitabilitas trading strategy berdasarkan metode yang digunakan oleh Jagadeesh \& Titman (1993), George \& Hwang (2004) dan Bhootra \& Hur (2013). Hasil dari penelitian ini strategi kontarian berdasarkan metode Jegadeesh \& Titman (1993) untuk periode mingguan lebih menguntungkan dibanding dengan strategi dan metode yang lain.

\subsection{Karakteristik Saham}

Portofolio winner memiliki kinerja lebih baik dari portofolio loser, atau sebaliknya. Namun menurut Mengoli (2004) banyak argumen dari akademisi yang menyatakan bahwa abnormal return dari trading strategi ini sesuai dengan resiko dari portofolio tersebut. Seperti saham dengan small size, high value, dan illiquid yang merupakan karakteristik saham berisiko. Model rasional juga menjelaskan bahwa return saham merupakan faktor dari risiko (Kryzanowsky dan He 2006). Fama dan French (1993) juga menangkap hubungan antara rata-rata return dengan kapitalisasi pasar dan book market ratio.

Kryzanowsky dan He (2008) mendemonstrasikan hubungan karakteristik perusahaan dengan strategi momentum dalam menjelaskan return saham. Penelitian Aarts dan Lehnert (2006) Mereka membentuk sembilan style portofolio yang berbeda dimensi dari small cap vs large cap didasarkan kepada kapitalisasi pasar perusahaan dan value vs growth didasarkan kepada B/M rasio. Sedangkan hasil penelitian (Du 2012) menyarankan penolakan terhadap asset-pricing models sebagai sumber momentum. Dan menerima misreaction sebagai sumber momentum.

Untuk melihat pengaruh size terhadap return portofolio momentum. Penelitian ini melakukan pengujian apakah terdapat perbedaan returns dari portofolio momentum hasil dari pengaruh proporsi investasi yang berbeda terhadap saham berdasarkan size. Sehingga penelitian ini menggunakan dua metode pembobotan portofolio equal-weighted dan valueweighted (Dobrynskaya 2017).

Portofolio equal-weighted merupakan portofolio dengan memberikan persentase bobot yang sama pada masing-masing saham dalam portofolio tersebut. Sedangkan portofolio value-weighted merupakan portofolio dengan memberikan persentase bobot berdasarkan nilai saham tersebut (Vilkov et al., (2014). Dalam penelitian ini value yang digunakan adalah size perusahaan, Sehingga pembobotan portofolio berdasarkan persentase size perusahaan berdasarkan size dari seluruh perusahaan dalam portofolio tersebut (Singal dan Qin 2013). 


\subsection{Hipotesis Penelitian}

\section{a. Return portofolio momentum}

Penelitian Dhankar \& Maheshwari (2016) yang menemukan adanya abnormal return momentum pada pasar saham India. Scrimgeour, Locke \& Gupta (2013), Stork (2013) menemukan return momentum pada sepuluh negara berbeda, Conrad \& Yavuz (2017) menemukan return momentum pada pasar saham NYSE, Amex, and Nasdaq , Moskowitz \& Daniel (2016) yang menemukan return momentum pada pasar saham USA, dan Brandao, Martins \& Martins (2016) menemukan return momentum pada pasar saham FSE Jerman.

Sedangkan penelitian Leung, Fung \& Yu (2019), dimana peneliti tidak menemukan return momentum di pasar saham China. Penelitian Aravind (2016) juga tidak menemukan return momentum jangka pendek pada portofolio yang dibentuk berdasarkan sektor di NSE Amerika. Penelitian Tanna \& Nnadi (2017) untuk pasar saham Rusia juga tidak menemukan return dari strategi momentum. Chen et al., (2015) juga tidak menemukan return momentum pada pasar saham China. Dewi \& Sasmikadewi (2017) tidak menemukan return momentum yang signifikan pada sektor finance di BEI.

Dari hasil penelitian diatas dapat dimunculkan hipotesis pertama untuk penelitian ini yaitu:

H1: Terdapat return portofolio momentum pada saham syariah terdaftar dalam JII 30

\section{b. Return portofolio kontrarian}

penelitian dari Leung, Fung \& Yu ( 2019), Chen et al. (2015) dimana peneliti menemukan return kontrarian di pasar saham China. Penelitian Tanna \& Nnadi (2017) juga menemukan return dari strategi kontrarian signifikan untuk pasar saham China dan Brasil. Dhankar \& Maheshwari (2016) yang menemukan adanya return kontrarian pada pasar saham India. Badjra \& Saputro (2016) menguji kinerja portofolio saham winner dibandingkan dengan kinerja portofolio saham loser serta signifikansi perbedaan antara kinerja portofolio saham winner-loser di BEI. Dan menemukan return kontrarian signifikan terjadi di BEI. Sedangkan Witiastuti \& Maharani (2015) menemukan return kontrarian di Bursa Efek Indonesia terjadi secara tidak signifikan.

Dari hasil penelitian diatas dapat dimunculkan hipotesis kedua untuk penelitian ini yaitu:

H1: Terdapat return portofolio kontarian pada saham syariah terdaftar dalam JII 30 


\subsection{Kerangka Pemikiran}

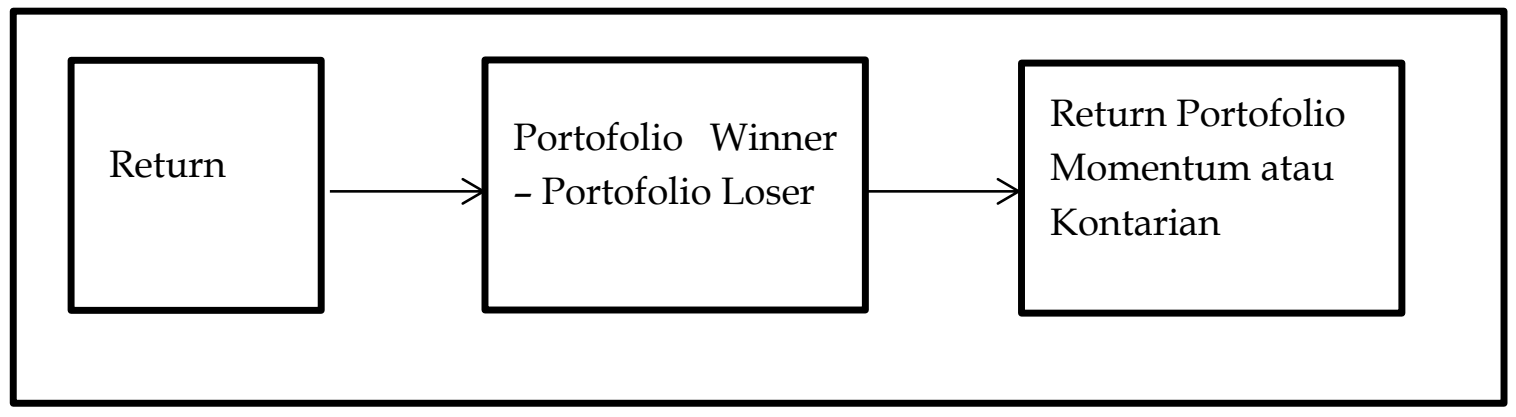

Gambar 1. Kerangka Pemikiran

\section{METODE PENELITIAN}

\subsection{Data dan Metode Pengumpulan Data}

Tujuan dari penelitian ini untuk melihat perbandingan return portofolio kontrarian pada saham syariah yang terdaftar dalam Jakarta Islamic Index 30 (JII 30) untuk periode 2010-2018. Jenis data yang digunakan pada penelitian ini adalah jenis data kuantitatif. Data sekunder dalam penelitian ini meliputi data: Harga saham, Indeks JII 30 dan Kapitalisasi pasar untuk periode 2010-2018. Data harga saham, JII didapat dari situs yahoo finance, data kapitalisasi pasar didapat dari laporan keuangan tahunan perusahaan. Data perusahaan-perusahaan yang masuk dalam JII 30 dalam periode 2010-2018 diperoleh dari website BEI.

\subsection{Metode Analisis dan Variabel Operasional}

Teknik analisis data dalam penelitian ini mengunakan metode yang digunakan adalah Jegadeesh dan Titman (1993). Pengunaan metode ini sejalan dengan metode yang digunakan oleh penelitian sebelumnya seperti Scrimgeour et al. (2013), Chen et al. (2015), Stork (2013) Conrad dan Yavuz (2017), dan Dhankar dan Maheshwari (2017). Dalam metode ini setiap periode $(\mathrm{t})$ formasi $(\mathrm{J})$ saham diberi peringkat berdasarkan kinerja return masa lalu, selanjutnya dibagi menjadi dua potofolio dimana saham dengan return tertinggi akan masuk portofolio winner dan saham dengan return terendah akan masuk kedalam portofolio loser. Strategi momentum menurut JT mengunakan metode membeli saham winner dan menjual saham loser. Setelah periode pembentukan dilanjutkan periode observasi saham tersebut (K) (holding). Return saham dihitung mengunakan formula:

$$
R_{j, t}=\frac{P_{j, t}-P_{j, t-1}}{P_{j, t-1}}
$$

Dimana:

$R_{j, t} \quad=$ Return saham bulanan

$P_{j, t} \quad=$ Harga saham pada bulan $\mathrm{t}$ 
$P_{j, t-1}=$ Harga saham bulan $\mathrm{t}-1$

Supaya penilaian return dari portofolio winner dan loser lebih ditail Dhankar dan Maheshwari (2017), menyarankan return yang digunakan dalam pembentukan portofolio (J) adalah market-adjusted excess return setiap bulan. Yang dihitung dengan mengunakan formula:

$u_{i, t}=R_{i, t}-R_{m, t}$

Dimana:

$u_{i, t} \quad=$ market-adjusted excess return

$R_{i, t} \quad=$ return saham $\mathrm{i}$ untuk periode $\mathrm{t}$

$R_{m, t} \quad=$ return pasar untuk periode $\mathrm{t}$

Dalam penelitian ini digunakan periode bulanan, pembentukan formasi pembentukan (J) dan observasi (K) digunakan jangka waktu 1, 3, 6 dan 12 bulanan. Selanjutnya saham dipilih berdasarkan kinerja return masa lalu, dimana lima saham dengan return terbaik akan masuk kedalam portofolio winner dan lima saham dengan kinerja return terburuk akan masuk ke portofolio loser.

Selanjutnya untuk strategi momentum average equal-weighted market-adjusted excess return (AR) portofolio winner dikurangi dengan average equal-weighted market-adjusted excess return (AR) dari portofolio loser (WML) dan sebaliknya untuk strategi kontarian average equal-weighted market-adjusted excess return (AR) portofolio loser dikurangi dengan average equal-weighted market-adjusted excess return (AR) portofolio winner (LMW) (Dhankar \& Maheshwari, 2017). Selain menggunakan equal-weighted, dalam penelitian ini digunakan value-weigted dalam menentukan return momentum dan kontrarian.

Signifikansi perbedaan kinerja portofolio saham winner-loser periode formasi dengan periode pengujian dilakukan dengan menggunakan SPSS 25 untuk menguji parametric onesample t-test. Dengan formula sebagai berikut (Bougie dan Sekaran 2017) :

$$
\mathrm{t}=\frac{X-\mu}{s / \sqrt{n}}
$$

Jika AR winner minus loser (WML) signifikan positif besar dari nol, hipotesis return momentum diterima. Dan sebaliknya jika AR loser minus winner (LMW) signifikan positif besar dari nol, hipotesis return kontarian diterima (Dhankar \& Maheshwari, 2017).

Dengan rumusan hipotesis penelitian dalam uji sample t-test : $\mathrm{H} 0=\mathrm{AR}$ sama dengan nol. 
$\mathrm{H} 1=\mathrm{AR}$ tidak sama dengan nol

\section{HASIL PENELITIAN DAN PEMBAHASAN}

\subsection{Statistik Deskriptif}

Penentuan terdapatnya return momentum dan kontarian pada suatu periode formasi dan observasi. Didasarkan pada AR portofolio winner minus loser (WML) jika WML positif artinya terdapat return momentum dan sebaliknya jika WML negatif terdapat return kontrarian.

a. Return Portofolio Momentum dan Kontrarian dengan Metode Pembobotan EqualWeighted

Tabel 2

Statistik Deskriptif Portofolio Momentum dan Kontarian dengan Metode Pembobotan Equal-Weighted

\begin{tabular}{ccccc}
\hline Formasi & 1 & 3 & 6 & 12 \\
\hline AR WML & $-0,0092$ & 0,0025 & $-0,0144$ & 0,1185 \\
Strategi & Kontarian & Momentum & Kontarian & Momentum \\
Mean & 0,0092 & 0,0025 & 0,0144 & 0,1185 \\
Maximum & 0,1918 & 0,1557 & 0,3409 & 0,5054 \\
Minimum & $-0,1849$ & $-0,2909$ & $-0,2842$ & $-0,6311$ \\
Std. Dev & 0,071 & 0,1116 & 0,1775 & 0,3416 \\
Observasi & 107 & 35 & 17 & 8 \\
\hline
\end{tabular}

Sumber: Data diolah

Berdasarkan tabel 2, hasil statistik deskriptif terlihat AR WML bernilai positif untuk formasi 3 dan 12 bulan sebesar 0,0025 (0,25\%) dan 0,1185 (11,85\%), sedangkan untuk formasi 1 dan 6 bulan AR WML bernilai negatif sebesar -0,0092 (-0,92\%) dan -0,0144 ($1,44 \%)$. Sehingga untuk portofolio metode pembobotan equal-weighted return portofolio momentum terjadi pada formasi 3 dan 12 bulan. Sedagkan return portofolio kontarian terjadi pada formasi 1 dan 6 bulan. Berdasarkan data deskriptif ditemukan return momentum dan kontarian pada saham syariah yang terdaftar di JII 30 periode 2010-2018. 


\section{b. Return Portofolio Momentum dan Kontarian dengan Metode Pembobotan Value- Weighted}

\section{Tabel 3}

Statistik Deskriptif Portofolio Momentun dan Kontrarian dengan Metode Pembobotan Value-Weighted

\begin{tabular}{ccccc}
\hline Formasi & 1 & 3 & 6 & 12 \\
\hline AR WML & $-0,0054$ & $-0,008$ & $-0,0598$ & 0,1814 \\
Strategi & Kontarian & Kontarian & Kontarian & Momentum \\
Mean & 0,0054 & 0,008 & 0,0598 & 0,1814 \\
Maximum & 0,1505 & 0,2876 & 0,3957 & 0,4696 \\
Minimum & $-0,223$ & $-0,1895$ & $-0,201$ & $-0,3683$ \\
Std. Dev & 0,0693 & 0,1215 & 0,1523 & 0,2804 \\
Observasi & 107 & 35 & 17 & 8 \\
\hline
\end{tabular}

Sumber: Data diolah

Berdasarkan tabel 3, hasil statistik deskriptif terlihat AR WML positif hanya untuk formasi 12 bulan sebesar 0,1814 (18,14\%). Sedangkan untuk formasi 1,3 dan 6 bulan AR WML bernilai negatif sebesar -0,0054 (-0,54\%), -0,008(-0,8\%) dan -0,0598 (5,98\%). Sehingga untuk portofolio metode pembobotan value-weighted return portofolio momentum hanya terjadi pada formasi 12 bulan. Sedangkan return portofolio kontarian terjadi untuk formasi 1,3 dan 6 bulan. Berdasarkan data deskriptif ditemukan return momentum dan kontarian pada saham syariah yang terdaftar di JII 30 periode $2010-2018$.

Hasil statistik deskriptif ini menunjukkan bahwa size perusahaan mempengaruhi return momentum dan kontrarian. Selanjutnya untuk membuktikan apakah return momentum dan kontrarian dari dua metode pembobotan tersebut signifikan atau tidak secara statistik, maka perlu dilakukan uji parametric one-sample t-test.

\subsection{Parametric One-Sample T-Test}

Berdasarkan tabel 4 Hasil Uji Statistik parametric one-sample t-test strategi momentum dan kontrarian dengan metode pembobotan Equal-weighted. Diketahui AR WML positif pada formasi 3 dan 6 bulan, sehingga terdapat return portofolio momentum terjadi pada formasi dan observasi 3 dan 6 bulan. Dengan return sebesar 0,00246 (0,25\%) dan 0,1185 (11,85\%). Secara statistik nilai sig (2-tailed) strategi momentum formasi dan observasi 3 dan 12 bulan sebesar 0,897 dan 0,359 lebih besar dari 0,05. sehingga H0 diterima dan H1 ditolak. Dengan demikian dapat disimpulkan bahwa return strategi momentum pada saham syariah di JII 30 periode 2010-2018 tidak signifikan secara statistik. 
Untuk formasi 1 dan 6 bulan AR WML bernilai negatif, sehingga terdapat return portofolio kontrarian terjadi pada formasi dan observasi 1 dan 6 bulan. Dengan return portofolio kontrarian sebesar 0,009155 (0,915\%) dan 0,0144 (1,44\%). Secara statistik nilai sig (2-tailed) strategi kontrarian formasi dan observasi 1 dan 6 bulan sebesar 0,185 dan 0,724 lebih besar dari 0,05. sehingga H0 diterima dan H1 ditolak. Dengan demikian dapat disimpulkan bahwa return strategi kontrarian pada saham syariah di JII 30 periode 2010-2018 tidak signifikan secara statistik.

\section{Tabel 4}

Hasil Uji Statistik Parametric One-Sample T-Test Pembobotan Equal-weighted

\begin{tabular}{llrrrrr}
\hline \multirow{2}{*}{ Periode } & \multirow{2}{*}{ Strategi } & $\begin{array}{l}\mathrm{t} \text { - } \\
\text { statistik }\end{array}$ & \multicolumn{1}{l}{$\begin{array}{l}\text { sig }(2- \\
\text { tailed })\end{array}$} & \multicolumn{1}{l}{$\begin{array}{l}\text { Mean } \\
\text { difference }\end{array}$} & Df & AR WML \\
\hline Formasi 1 bulan & Kontarian & 1,334 & 0,185 & 0,00916 & 106 & $-0,0092$ \\
Formasi 3 bulan & Momentum & 0,13 & 0,897 & 0,00246 & 34 & 0,00246 \\
Formasi 6 bulan & Kontarian & 0,334 & 0,742 & 0,01439 & 16 & $-0,0144$ \\
Formasi 12 bulan & Momentum & 0,98 & 0,359 & 0,11847 & 7 & 0,118 \\
\hline Sumber: Data diolah & & & & & &
\end{tabular}

Berdasarkan tabel 5 Hasil Uji Statistik parametric one-sample t-test portofolio dengan metode Pembobotan value-weighted. Diketahui AR WML bernilai positif pada formasi 12 bulan, sehingga terdapat return portofolio momentum terjadi pada formasi dan observasi 12 bulan. Dengan return sebesar 0,1814 (18,14\%). Secara statistik nilai sig (2-tailed) strategi momentum formasi dan observasi 12 bulan sebesar 0,109 lebih besar dari 0,05. sehingga H0 diterima dan H1 ditolak. Dengan demikian dapat disimpulkan bahwa return portofolio momentum pada saham syariah di JII 30 periode 2010-2018 tidak signifikan secara statistik.

Untuk formasi 1,3 dan 6 bulan AR WML bernilai negatif, sehingga terdapat return portoflio kontrarian terjadi pada formasi dan observasi 1, 3 dan 6 bulan. Dengan return portofolio kontrarian sebesar 0,0054 (0,54\%), 0,00796 (0,796\%) dan 0,0595 (5,95). Secara statistik nilai sig (2-tailed) strategi kontrarian formasi dan observasi 1, 3 dan 6 bulan sebesar 0,423, 0,701 dan 0,125 lebih besar dari 0,05. Sehingga H0 diterima dan H1 ditolak. Dengan demikian dapat disimpulkan bahwa return portofolio kontarian pada saham syariah di JII 30 periode 2010-2018 tidak signifikan secara statistik. 
Andalas Management Review, Vol. 4 No. 1, 2020

Tabel 5

Hasil Uji Statistik Parametric One-Sample T-Test Pembobotan Value-Weighted

\begin{tabular}{llrrrrrr}
\hline Periode & Strategi & $\begin{array}{l}\text { t- } \\
\text { statistik }\end{array}$ & $\begin{array}{l}\text { sig (2- } \\
\text { tailed) }\end{array}$ & $\begin{array}{l}\text { Mean } \\
\text { difference }\end{array}$ & Df & AR WML \\
\hline formasi 1 bulan & Kontarian & 0,804 & 0,423 & 0,0053 & 106 & $-0,0053$ \\
formasi 3 bulan & Kontarian & 0,388 & 0,7 & 0,0079 & 34 & $-0,0079$ \\
formasi 6 bulan & Kontarian & 1,62 & 0,124 & 0,0598 & 16 & $-0,0598$ \\
formasi 12 bulan & Momentum & 1,829 & 0,109 & 0,1814 & 7 & 0,1814 \\
\hline Sumber: Data diolah & & & & & & &
\end{tabular}

\subsection{Pembahasan}

\section{a. Return portofolio momentum}

Strategi momentum dilakukan dengan cara membeli saham yang sebelumnya memiliki kinerja baik dan menjual saham yang sebelumnya memiliki kinerja buruk dengan tujuan untuk mendapatkan return di atas return pasar (Jegadeesh \& Titman, 1993). Strategi momentum menurut Dhankar \& Maheshwari (2017) mengunakan karakteristik dari kelanjutan harga saham untuk jangka pendek, dimana harga cenderung bergerak searah untuk periode tiga sampai dua belas bulan.

Berdasarkan tabel 4 dan tabel 5 dapat dilihat AR portofolio momentum dengan metode pembobotan equal-weighted dan value-weighted. Return momentum portofolio pembobotan equal-weighted terjadi pada formasi dan observasi 3 bulan dengan ratarata selisih return sebesar 0,0025 (0,25\%). Selanjutnya return strategi momentum pada periode formasi dan observasi 12 bulan dengan rata-rata selisih return sebesar 0,1185 (11,85\%). Namun secara statistik return momentum pada periode 3 dan 12 bulan ini tidak signifikan dengan sig (2-tailed) sebesar 0,897 dan 0,359 lebih besar dari 0,05.

Return Momentum Portofolio pembobotan value-weighted hanya terjadi pada formasi dan observasi 12 bulan dengan rata-rata selisih return sebesar 0,182 (18,2\%). Tetapi secara statistik return momentum pada periode 12 bulan ini tidak signifikan karena sig (2-tailed) sebesar 0,109 lebih besar dari 0,05.

Dalam penelitian ini ditemukan return momentum pada formasi dan observasi 3 bulan dan 12 bulan untuk portofolio dengan pembobotan equal-weighted. Sedangkan untuk portofolio dengan pembobotan value-weighted return momentum ditemukan pada formasi dan observasi 12 bulan. Namun secara statistik tidak signifikan, sehingga secara statistik tidak ditemukan return strategi portofolio momentum saham syariah di JII 30 dengan dua metode pembobotan tersebut. Tidak signifikannya return momentum pada saham syariah yang tergabung dalam indeks JII 30. Menunjukkan bahwa anomali ini tidak terjadi pada JII 30, ini mungkin disebabkan karena mayoritas 
saham yang tergabung dalam JII 30 berasal dari perusahaan-perusahaan yang bagus secara fundamental dan menjadi acuan dalam pembentukan reksadana syariah.

Hasil penelitian ini sejalan dengan penelitian Leung, Fung \& Yu ( 2019), dimana peneliti tidak menemukan return momentum di pasar saham China. Penelitian Aravind (2016) juga tidak menemukan return momentum jangka pendek pada portofolio yang dibentuk berdasarkan sektor di NSE Amerika. Penelitian Tanna \& Nnadi (2017) untuk pasar saham Rusia juga tidak menemukan return dari strategi momentum. Chen et al. (2015) juga tidak menemukan return momentum pada pasar saham China. Dewi \& Sasmikadewi (2017) tidak menemukan return momentum yang signifikan pada sektor finance di BEI.

Namun penelitian ini tidak sejalan dengan hasil penelitian Dhankar \& Maheshwari (2016) yang menemukan adanya return momentum pada pasar saham India. Scrimgeour, Locke \& Gupta (2013), Stork (2013) menemukan return momentum pada sepuluh negara berbeda, Conrad \& Yavuz (2017) menemukan return momentum pada pasar saham NYSE, Amex, and Nasdaq , Moskowitz \& Daniel (2016) yang menemukan return momentum pada pasar saham USA, dan Brandao, Martins \& Martins (2016) menemukan return momentum pada pasar saham FSE Jerman.

\section{b. Return Portofolio Kontrarian}

Strategi kontrarian, yang didasarkan pada hipotesis overreaction, memberi peringkat saham berdasarkan kinerja masa lalu mereka dan merekomendasikan untuk membeli saham loser di masa dan menjual winner di masa lalu (Gunasekarage \& Kot, 2007). Dalam rangka mendapatkan saham-saham yang salah harga, dan akan mengalami pembalikan arah harga (Galariotis, 2014).

Berdasarkan tabel 4 dan tabel 5 dapat dilihat AR portofolio kontrarian dengan metode pembobotan equal-weighted dan value-weighted. Return portofolio kontrarian dengan pembobotan equal-weighted terjadi pada formasi dan observasi 1 bulan dengan rata-rata selisih return sebesar $-0,0092(-0,92 \%)$. Selanjutnya return strategi kontrarian pada periode formasi dan obsesrvasi 6 bulan dengan rata-rata selisih return sebesar -0,0144 (1,44\%). Namun secara statistik return kontrarian pada periode 1 dan 6 bulan ini tidak signifikan dengan sig t statistik sebesar 0,186 dan 0,689 lebih besar dari 0,05.

Return portofolio kontrarian dengan metode pembobotan value-weighted terjadi pada formasi dan observasi 1 bulan dengan rata-rata selisih return sebesar 0,00554 (0,54\%). 
Selanjutnya return strategi kontrarian pada periode formasi dan observasi 3 bulan dengan rata-rata selisih return sebesar 0,008 (0,8\%) dan pada periode formasi dan observasi 6 bulan dengan rata-rata selisih return sebesar 0,0599 (5,99\%). Namun secara statistik return kontrarian pada periode 1, 3 dan 6 bulan ini tidak signifikan karena sig (2-tailed) sebesar 0,423, 0,701 dan 0,125 lebih besar dari 0,05.

Dalam penelitian return portofolio kontrarian terjadi pada formasi dan observasi 1 dan 6 bulan untuk metode pembobotan equal-weighted, dan untuk metode pembobotan portofolio value-weighted return kontrarian terjadi pada formasi dan observasi 1,3 dan 6 bulan. Namun secara statistik tidak ada return portofolio kontrarian yang signifikan. Tidak signifikannya return portofolio kontrarian pada saham syariah yang tergabung dalam indeks JII 30. Menunjukkan bahwa anomali ini tidak terjadi pada JII 30, ini mungkin disebabkan karena mayoritas saham yang tergabung dalam JII 30 berasal dari perusahaan-perusahaan yang bagus secara fundamental dan menjadi acuan dalam dalam reksadana syariah.

Hasil penelitian ini sejalan dengan penelitian Witiastuti \& Maharani (2015) menemukan return kontarian terjadi di Bursa Efek Indonesia baik pada periode triwulan, periode semester, maupun pada periode tahunnan. Sementara berdasarkan hasil uji statistik menunjukkan bahwa return kontrarian di Bursa Efek Indonesia terjadi secara tidak signifikan.

Sementara hasil penelitian ini tidak sejalan dengan penelitian dari Leung, Fung \&Yu ( 2019), Chen et al., (2015) dimana peneliti menemukan return kontrarian di pasar saham China. Penelitian Tanna \& Nnadi (2017) juga menemukan return dari strategi kontarian signifikan untuk pasar saham China dan Brasil. Dhankar \& Maheshwari (2016) yang menemukan adanya return kontrarian pada pasar saham India. Badjra \& Saputro (2016) menguji kinerja portofolio saham winner dibandingkan dengan kinerja portofolio saham loser serta signifikansi perbedaan antara kinerja portofolio saham winner-loser di BEI. Dan menemukan return kontrarian signifikan terjadi di BEI.

Konsep EMH yang diperkenalkan oleh Fama (1970) dimana level market efficiency dibagi menjadi tiga yaitu: pertama weak-form market efficiency, kedua semi strong-form market efficiency dan yang ketiga strong-form market efficiency. Berdasarkan hasil uji statistik dalam penelitian ini, return portofolio momentum dan kontarian tidak ditemukan pada saham syariah yang terdaftar dalam JII 30. Sehingga hasil penelitian ini mengkorfirmasi bahwa saham yang tergabung dalam indeks JII 30 dapat 
diklasifikasikan sebagai semi strong-form market efficiency. Dimana pada pasar semistrong abormal return portofolio saham tidak bisa didapat dengan menggunakan informasi dari harga saham masa lalu.

Meskipun return dari portofolio momentum dan kontrarian pada saham syariah yang terdaftar dalam JII 30 periode tidak signifikan secara statistik. Namun investor masih bisa menggunakan strategi ini dalam meningkatkan return dari berinvestasi pada saham syariah karena strategi portofio ini masih memberikan return yang bisa diperoleh oleh investor dengan menggunakan strategi portofolio momentum dan kontrarian ini.

\section{KESIMPULAN DAN SARAN}

Berdasarkan analisis data dan pembahasan data yang telah diuraikan pada bab-bab sebelumnya tentang return portofolio momentum dan kontrarian dengan metode pembobotan equal-weighted dan value-weighted pada saham syariah yang tergabung dalam Jakarta Islamic Index 30 (JII 30). Maka dapat diambil kesimpulan sebagai berikut : Metode yang digunakan dalam menghitung return momentum dan kontrarian dalam penelitian ini adalah metode Jegadeesh dan Titman (1993). Dimana saham dengan return tertinggi akan masuk ke portofolio winner dan saham dengan return terendah akan masuk kedalam portofolio loser. Periode formasi dan observasi dalam penelitian ini adalah 1,3, 6 dan 12 bulan. WML positif memperlihatkan adanya return momentum dan sebaliknya WML negatif mengidentifikasi adanya return kontrarian. Untuk melihat adanya tidaknya perbedaan return saham dari kapitalisasi pasar yang berbeda. Perhitungan return portofolio dibuat berdasarkan equal-weighted dan value-weighted.

Hasil penelitian ini menemukan adanya return momentum periode formasi 3 dan 12 bulan untuk portofolio dengan pembobotan equal-weighted dan untuk portofolio dengan metode pembobotan value-weighted return momentum ditemukan pada formasi 12 bulan. Namun secara statistik tidak ada return momentum yang signifikan secara statistik.

Return kontarian ditemukan pada formasi 1 dan 6 bulan untuk metode pembobotan portofolio berdasarkan equal-weighted. Sedangkan return kontarian formasi 1,3, dan 6 bulan ditemukan untuk portofolio dengan pembobotan value-weighted. Secara statistik tidak ada return dari strategi kontrarian yang signifikan.

Berdasarkan hasil penelitian dan kesimpulan yang diperoleh, maka peneliti menyimpulkan beberapa saran bagi penelitian selanjutnya, yaitu : Penelitian selanjutnya 
disarankan untuk melihat bagaimana pengaruh risiko pasar, profitabilitas, investasi dan makro ekonomi terhadap return momentum dan kontarian. Penelitian selanjutnya disarankan untuk melihat return momentum dan kontrarian pada saat pasar bullish atau bearish.

\section{DAFTAR PUSTAKA}

Aart, F., \& Lehnert, T. (2006), “On Syle Momentum Strategies”, Applied Economics Letters, Vol. 12, pp. 795-799.

Arfianto, D. E., \& Maharani, E. (2016), “Analisis Pengaruh Momentum, Trading Volume dan Size terhadap Disposition Effect dan Return Aplikasi Cross Sectional Regression (studi pada indeks saham kompas 100 tahun 2012-2015)", Diponegoro Journal of Management. Vol. 6, No. 1, Th. 2016, Hal. 1-15 ISSN.

Badjra, B., \& Saputro, N. (2016), “Kinerja Portofolio Saham berdasarkan Strategi Investasi Momentum pada Industri Manufaktur", E-Jurnal Manajemen Unud, Vol. 5, No.1, pp. 623-649.

Barroso, P., \& Santa-Clara, P. (2015), "Momentum has its Moments", Journal of Financial Economics, Vol. 116, No. 1,pp. 111-120.

Bhootra, A. (2018), Gross Profitability and Momentum, Emerald Insight.

Bougie, R., \& Sekaran, U. (2017), Research Methods for Business, Ed. 7, Wiley.

Brandao, E., Martins, V., \& Martin, J. (2016), “Momentum: Strategies, Size, and Risk Factor”, Working Papers, ISSN: 0870-8541.

Bursa Efek Indonesia. (n.d.), available at: http://www.idx.co.id.

Chen, Q., Hua, X., \& Jiang, Y. (2015), “Contrarian Strategy and Herding Behaviour in the Chinese Stock Market", The European Journal of Finance.

Conrad, J., \& Yavuz, D. M. (2017), “Momentum and Reversal: Does What Goes up Always Come Down?", Review of Finance, Vol. 21, No. 2, pp. 555-581.

Daniel, K., Hirshleifer, D., \& Subrahmanyam, A. (1998), “Psychology and Security Market Under- and Overreactions", The Journal of Finance, Vol. 53, No. 6,pp. 18391885.

De Bondt, M. F. W., \& Thaler, R. (1985), "Does the Stock Market Overreact?", The Journal of Finance.

Dewi, R. M., \& Sasmikadewi, A. I. (2017), “Perbandingan Kinerja Portofolio Saham WinnerLoser berdasarkan Strategi Investasi Momentum", E-Jurnal Manajemen Unud, Vol. 6, No. 2, pp. 857-888, ISSN: 2302-8912. 
Dhankar, R. S., \& Maheshwari, S. (2017), “Momentum Anomaly: Evidence from the Indian Stock Market", Journal of Advances in Management Research, Vol. 14 Iss 1 pp.-. Emerald Insight.

Dhankar, R. S., \& Maheshwari, S. (2016), “Momentum and Contrarian Profitability: Insights from the Indian Stock Market under Alternative Approaches". Asian Journal of Humanities and Social Sciences (AJHSS) Vol. 4, Issue -1, May 2016.

Doan, M. P., \& Brooks, R. (2014), “Concurrent Momentum and Contrarian Strategies in the Australian Stock Market", Australia Journal of Management, pp. 1-30.

Ding, Du (2012), "Momentum and behavioral finance", Managerial Finance, Vol. 38 Iss 4 pp. 364 - 379, Emerald Insight

French, K. R., \& Fama, E. F. (1993), “Common Risk Factors in the Returns on Stocks and Bonds", Journal of Financial Economics, Vol. 33, No. 1, pp. 3-56.

Galariotis, C. E. (2014), "Contrarian and Momentum Trading: A Review of the Literature", Review of Behavioral Finance, Vol. 6 Iss 1, pp. 63-82, Emerald Insight.

Gunasekarage, A., \& Kot, W. H. (2007), “Article Information:Return-Based Investment Strategies in the New Zealand Stock Market: Momentum Wins", Pacific Accounting Review, Vol. 19 Iss 2, pp. 108-124, Emerald Insight.

Jegadeesh, N., \& Titman, S. (1993), “Return to Buying Winners and Selling Losers: Implications for Stock Market Efficiency", The Journal of Finance, Vol. 48, No. 1, pp. 65-91.

Jones, P. C. (2010), Investments Principles and Concepts , Ed. 11, John Wiley \& Sons.

Kaul, G., \& Conrad, J. (1998), “An Anatomy of Trading Strategies”, Review of Financial Studies, Vol. 11, No. 3, pp. 489-519.

Khairunnisa, Rikumahu, B., \& Valentina, E. (2017), “Analisis Price Reversal di Bursa Efek Indonesia: Studi Kasus Indeks Bisnis 27 periode Januari 2015 - Desember 2016", E-Proceeding of Management, Vol. 4, No. 1, April 2017, ISSN : 2355-9357.

Kryzanowski, L., \& He, Z. (2006), “A Reformulated Asset Pricing Model Based on Contrarian Strategies", Studies In Economics and Finance", Vol. 23 Iss 3 pp. 185201, Emerald Insight.

Leung, K. W., Fung, G. H., \& Yu L. (2019), “Momentum and Contrarian Trading Strategy: Which One Works Better in Chinese Stock Market", International Review of Economics and Finance, Vol. 62, 2019, pp. 87-105, Elsevier.

Liao, C. C. (2017), “Momentum Trading, Contrarian Trading and Smart Money Manipulation", International Business Research, Vol. 10, No. 2, 2017, ISSN 1913- 
9004.

Marcus, J. A., Kane, A., \& Bodie, Z. (2011), Investments and Portofolio Management, Ed. 9 , McGraw-Hill.

Mengoli, S. (2004), "On the Source of Contrarian and Momentum Strategies in the Italian Equity Market", International Review of Financial Analysis, Vol. 13, No. 3, pp. 301-331.

Moskowitz, J. T., \& Daniel, K. (2016), "Momentum Crashes. Journal of Financial Economics", Vol. 122, 2016 , pp. 221-247, Elsevier.

Nugroho, Y. B. (2008), "Profitabilitas Strategi Momentum di Bursa Efek Indonesia", Jurnal Siasat Bisnis, Vol. 12, No. 3, Hal. 175-186.

Otoritas Jasa Keuangan (n.d.), available at: http:/ /ojk.go.id.

Scrimgeor, F., Locke, S., \& Gupta, K. (2013), “Profitability of Momentum Returns Under Alternative Approaches", International Journal of Managerial Finance, Vol. 9 Iss 3, pp. 219-246.

Singal, V., \& Qin, N. (2018), Equal-Weighting versus Value-Weighting: Theory and Practice, SSRN, Elsevier.

Stork, A. P. (2013), “The Intertemporal Mechanics of European Stock Price Momentum. Studies in Economics and Finance", Vol. 28 Iss 3, pp. 217-232, Emerald Insight.

Tanna, S. \& Nnadi, M. (2017), “Accounting Analyses of Momentum and Contrarian Strategies in Emerging Markets", Asia-Pacifik Journal of Accounting \& Economics, ISSN: 1608-1625.

Vilkov, G., Uppal, R., \& Plyakha, Y. (2014), “Equal or Value Weighting? Implications for Asset-Pricing Tests", Working Paper EDHEC-Risk Institute.

Witiastuti, S., \& Maharani, S. (2015), “Fenomena Market Overreaction di Bursa Efek Indonesia", Management Analysis Journal, Vol. 4, No. 1, Th. 2015. 